\title{
Marine archaea and archaeal viruses under global change
}

\section{[version 1; peer review: 2 approved]}

\section{Roberto Danovaro (iD1, $2^{*}$, Eugenio Rastelli ${ }^{1,2^{*}}$, Cinzia Corinaldesi ${ }^{3}$, Michael Tangherlini², Antonio Dell'Anno ${ }^{2}$}

\author{
${ }^{1}$ Stazione Zoologica Anton Dohrn, Villa Comunale, Naples, Italy \\ 2Department of Life and Environmental Sciences, Polytechnic University of Marche, Ancona, Italy \\ ${ }^{3}$ Department of Sciences and Engineering of Materials, Environment and Urbanistics, Polytechnic University of Marche, Ancona, \\ Italy \\ * Equal contributors
}

V1 First published: 27 Jul 2017, 6(F1000 Faculty Rev):1241

https://doi.org/10.12688/f1000research.11404.1

Latest published: 27 Jul 2017, 6(F1000 Faculty Rev):1241

https://doi.org/10.12688/f1000research.11404.1

\section{Abstract}

Global change is altering oceanic temperature, salinity, $\mathrm{pH}$, and oxygen concentration, directly and indirectly influencing marine microbial food web structure and function. As microbes represent $>90 \%$ of the ocean's biomass and are major drivers of biogeochemical cycles, understanding their responses to such changes is fundamental for predicting the consequences of global change on ecosystem functioning. Recent findings indicate that marine archaea and archaeal viruses are active and relevant components of marine microbial assemblages, far more abundant and diverse than was previously thought. Further research is urgently needed to better understand the impacts of global change on virus-archaea dynamics and how archaea and their viruses can interactively influence the ocean's feedbacks on global change.

Keywords

Marine archaea, archaeal viruses, Thaumarchaeota

\section{Open Peer Review \\ Approval Status \\ 1 \\ 2 \\ version 1 \\ 27 Jul 2017 \\ Faculty Reviews are review articles written by the prestigious Members of Faculty Opinions. The articles are commissioned and peer reviewed before publication to ensure that the final, published version is comprehensive and accessible. The reviewers who approved the final version are listed with their names and affiliations. \\ 1. Stéphan Jacquet, Institut National de la Recherche Agronomique, UMR CARRTEL, Thonon-les-Bains, France \\ 2. Jed A. Fuhrman, University of Southern California, Los Angeles, USA}

Any comments on the article can be found at the end of the article. 
Corresponding author: Roberto Danovaro (r.danovaro@univpm.it)

Competing interests: The authors declare that they have no competing interests.

Grant information: This work was conducted within the frame of the Flagship Project RITMARE (Italian Research for the Sea) coordinated by the Italian National Research Council and funded by the Italian Ministry of Education, Universities, and Research within the National Research Program 2011-2013, the Project EXPLODIVE (FIRB2008, contract no. I31J10000060001, PICC), the EU Project MIDAS (Managing Impacts of Deep-seA resource exploitation, grant agreement no. 603418), and the project MERCES (Marine Ecosystem Restoration in Changing European Seas; European Union's Horizon 2020 research and innovation program, grant agreement no. 689518)

The funders had no role in study design, data collection and analysis, decision to publish, or preparation of the manuscript.

Copyright: @ 2017 Danovaro R et al. This is an open access article distributed under the terms of the Creative Commons Attribution License, which permits unrestricted use, distribution, and reproduction in any medium, provided the original work is properly cited.

How to cite this article: Danovaro R, Rastelli E, Corinaldesi $C$ et al. Marine archaea and archaeal viruses under global change [version 1; peer review: 2 approved] F1000Research 2017, 6(F1000 Faculty Rev):1241 https://doi.org/10.12688/f1000research.11404.1

First published: 27 Jul 2017, 6(F1000 Faculty Rev):1241 https://doi.org/10.12688/f1000research.11404.1 


\section{Recent insights on marine archaea and their respective viruses}

Research on archaea has increased exponentially over the last few years, but marine archaea and the viruses able to infect them have received little attention despite their global relevance ${ }^{1-6}$ (Figure 1). Moreover, most of the current knowledge on archaea and archaeal viruses is based on culturable extremophiles inhabiting peculiar high-temperature, high-salinity, or low-pH environments ${ }^{7-9}$, while the archaeal taxa most represented in the ocean remain almost completely uncultured ${ }^{10-16}$, as well as their viruses ${ }^{17}$. Several new archaeal phyla have been described in the last 15 years thanks to gene surveys, metagenomics studies, and single-cell next-generation sequencing projects ${ }^{16,18-22}$. While the earliest archaeal phylogenetic trees reported only two phyla (i.e. the Crenarchaeota and Euryarchaeota), the current view of the taxonomic and functional diversity of archaea has greatly expanded. Besides Euryarchaeota, three additional archaeal clades have been recently proposed: the TACK superphylum (including Crenarchaeota, Korarchaeota, Thaumarchaeota, Aigarchaeota, and Bathyarchaeota), the DPANN superphylum (including archaeal Richmond Mine acidophilic nanoorganism [ARMAN], Diapherotrites, Nanohaloarchaea, Parvarchaeota, Aenigmarchaeota, and Nanoarchaeota), and the ASGARD superphylum (including Lokiarchaeota, Thorarchaeota, Odinarchaeota, and Heimdallarchaeota) ${ }^{16,23-27}$. Moreover, findings based on current culture-independent molecular approaches point out that a large fraction of archaeal diversity is still awaiting discovery ${ }^{28}$.

Marine ecosystems host $3.9 \times 10^{30}$ prokaryotic (i.e. bacterial and archaeal) cells and $4.3 \times 10^{31}$ viruses $^{29}$. These components represent $\sim 90 \%$ of the global microbial abundance and largely contribute to organic matter cycling and biogeochemical processes on a global scale ${ }^{29,30}$. Most of such microbes live in deep-sea ecosystems (i.e. waters and sediments below $200 \mathrm{~m}$ water depth), which cover more than $65 \%$ of the Earth's surface and represent $95 \%$ of the biosphere volume ${ }^{31,32}$. Archaea are ubiquitous and abundant in marine ecosystems. Although bacteria tend to outnumber archaea in the world's oceans, archaea make an important contribution to microbial biomass in deep waters (with abundances equivalent to those of bacteria at depths of $>1000 \mathrm{~m}$ ) and in surface and subsurface marine sediments ${ }^{3,31}$. Different archaeal taxa can be numerically dominant in specific environmental conditions. In oxygenated waters and sediments, four major groups of archaea prevail, including marine group (MG)-I Thaumarchaeota and MG-II, MG-III, and MG-IV Euryarchaeota $^{15}$, while novel archaeal taxa have been recently identified in anoxic ecosystems including marine subsurface sediments ${ }^{16,27}$. MG-I Thaumarchaeota are among the most abundant microbes in the deep ocean, and they play key roles in global $\mathrm{C}$ and $\mathrm{N}$ cycles through $\mathrm{CO}_{2}$ fixation coupled with ammonium/ ammonia oxidation, which can generate the greenhouse gas nitrous oxide $\left(\mathrm{N}_{2} \mathrm{O}\right)$ as a by-product ${ }^{3,11,14,33}$. MG-II Euryarchaeota generally prevail in surface waters ${ }^{15,34}$ and can display heterotrophic/ photoheterotrophic lifestyles ${ }^{35,36}$, while the physiology and metabolism of MG-III and MG-IV Euryarchaeota, preferentially inhabiting the ocean interior at relatively low abundances, still remain poorly understood ${ }^{15,37}$. In subsurface and anoxic sediments, still poorly resolved archaeal groups, such as anaerobic methanotrophic archaea (ANME) and members of the deep sea archaeal group (DSAG) and of the miscellaneous Crenarchaeota group (MCG), can account for a large fraction of prokaryotic standing stocks ${ }^{25,38-40}$ and are thought to significantly contribute to biogeochemical cycles and global ecosystem functioning ${ }^{21,26,27,41}$.

Concerning archaeal viruses, a putative provirus has been identified in a recently isolated MG-I thaumarchaeon ${ }^{42}$, and DNA sequences
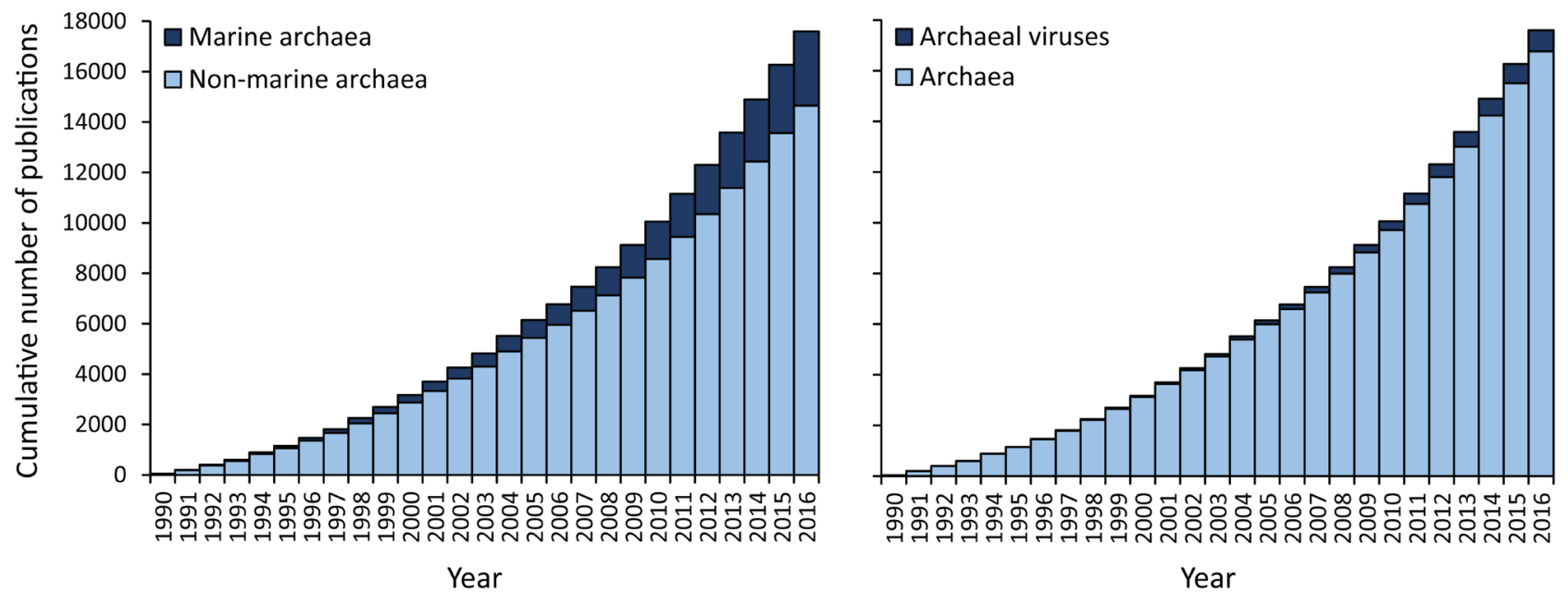

Figure 1. Number of publications regarding archaea, subdivided into publications on marine or non-marine archaea (left chart) and publications on archaea or on viruses of archaea (right chart), as searched through the Web of Science database. The following keywords were used in the searches for archaea: archaea or archaebacteria or archaeobacteria. The following keywords were used in the searches for marine archaea: marine archaea or ocean archaea or sea archaea, also using the terms archaebacteria or archaeobacteria. The following keywords were used in the searches for viruses of archaea: archaea virus or archaebacteria virus or archaeobacteria virus. Research on archaea has increased over the past few decades, but relatively little focus has been directed towards marine archaea and archaeal viruses, despite the current compelling evidence of their relevant role at the global level. 
of putative viruses infecting MG-I Thaumarchaeota are abundant in seawater and sediments $\mathrm{s}^{3,4,43-45}$. Increasing evidence suggests that marine viruses infecting members of other dominant archaeal taxa are widespread and likely highly abundant both in the water column (e.g. putative viruses of pelagic MG-II Euryarchaeota) $)^{5,6}$ and in sediments (e.g. putative viruses of anaerobic methane-oxidizing euryarchaea ${ }^{46}$ and other still-unclassified archaeal viruses ${ }^{47}$ ). All of these viruses are still uncultured ${ }^{17}$, and the virus-archaea interactions occurring in marine ecosystems remain largely unknown ${ }^{3,4,48}$.

\section{Impacts of climate changes on marine archaea}

Since the beginning of the industrial revolution, anthropogenic activities have progressively enhanced terrestrial fluxes of greenhouse gases, increasing atmospheric concentrations of $\mathrm{CO}_{2}, \mathrm{CH}_{4}$, and $\mathrm{N}_{2} \mathrm{O}$ by $40 \%, 150 \%$, and $20 \%$, respectively ${ }^{49,50}$. This process has triggered climate changes causing warming, oxygen depletion, and acidification of the oceans as well as altered precipitation regimes, increased ice melting, and shifting patterns (generally, a decrease) of global primary production and carbon export to the ocean interior. All these changes have been reported to influence the biodiversity and functioning of marine ecosystems $\mathrm{s}^{51-55}$.

Marine archaea are key actors in the cycling of all the aforementioned greenhouse gases ${ }^{26,33,56-58}$. Our knowledge on the potential consequences of global climate changes on archaea is very limited and almost entirely based on studies of MG-I Thaumarchaeota ${ }^{11,13,33}$. Indeed, the recent success in culturing several MG-I Thaumarchaeota as pure isolates or in enriched mixed cultures has provided the first insights into their responses to changes in seawater temperature, oxygen concentrations, and $\mathrm{pH}^{11,13,14,33,56}$. The emerging view suggests high functional diversity and metabolic plasticity within the MG-I Thaumarchaeota, including members with different sensitivities to seawater warming, acidification, and oxygen depletion $^{11,14,33}$. Thus, specific MG-I Thaumarchaeota more adapted to such conditions could be competitively advantaged in future scenarios of global change $\mathrm{e}^{11,33}$.

Global warming is expected to have a stronger impact on marine ecosystems at high latitudes ${ }^{51,59}$, where pelagic and benthic MG-I Thaumarchaeota are particularly abundant and highly metabolically active $\mathrm{e}^{3,45,60,61}$. While primary production is expected to decrease at tropical and mid-latitudes, an increase is expected at high latitudes ${ }^{51,62-64}$. If confirmed, these shifts will alter the quantity and quality of food supply to the seafloor ${ }^{65}$, with downstream consequences on organic matter remineralization and supply of ammonia needed for sustaining the metabolism of nitrifying MG-I Thaumarchaeota. On one hand, such changes could have a differential impact on MG-I Thaumarchaeota at different latitudes ${ }^{45}$. On the other hand, inter-strain hallmarks of different members within MG-I Thaumarchaeota, including chemotaxis, motility, and versatility in organic substrate utilization, might be factors able to influence their relative distribution under future scenarios of global change ${ }^{14}$. Current evidence suggests that the shifts in food supply caused by global change $^{51,65}$ could influence also the distribution and abundance of MG-II Euryarchaeota, which are believed to be heterotrophs ${ }^{15,35,36}$ and whose abundance in benthic deep-sea ecosystems can be controlled by the availability of organic matter ${ }^{45}$. Nonetheless, the lack of available culturable strains for this and other newly discovered archaeal taxa $\mathrm{a}^{15,16}$ limits our ability to predict their metabolic/physiological response to global changes.

Recent studies have provided the first insights into the possible effects of temperature changes on archaeal assemblages. While manipulative experiments have suggested no significant effects of temperature shifts from 8 to $20^{\circ} \mathrm{C}$ on the rates of ammonia oxidation by archaea ${ }^{66}$, temperature itself has been shown to be a significant macroecological driver of the global patterns of distribution of MG-I Thaumarchaeota in benthic deep-sea ecosystems ${ }^{45}$. In polar ecosystems, the enhanced ice melting due to global warming has the potential to influence the composition and relative abundance of marine archaea by releasing ice-associated microbes ${ }^{67,68}$ and favoring specific MG-I Thaumarchaeota pre-adapted to grow at lower salinity ${ }^{11}$. Moreover, as nitrification in Thaumarchaeota is dependent upon oxygen levels and is inhibited by anoxic conditions ${ }^{33}$, the expansion of oxygen-depleted marine zones induced by warming and eutrophication can contribute to influence on the composition and functioning of archaeal assemblages ${ }^{69-71}$. However, the impacts of such changes, including the relative feedbacks of different archaeal taxa and the consequences on carbon and nutrient cycling, remain virtually unexplored ${ }^{71}$.

\section{Virus-archaea interactions in the oceans under global change}

Daily virus-induced mortalities of marine prokaryotes are in the range of $0.1-40 \%$ of the standing stock $^{3,72,73}$, implying that every year approximately $10^{30}$ to $10^{32}$ prokaryotic cells are infected and killed by viruses in marine ecosystems ${ }^{29}$. However, the extent to which viruses specifically impact archaea in the oceans is largely unknown, and this represents a significant gap for a better comprehension of the functioning of the world's oceans.

The relative contribution of archaea to the prokaryotic stock has been reported to increase with increasing water column depth and along the vertical profile of the sediment ${ }^{15,39}$. Also, viruses are suggested to play more relevant roles delving deeper in the ocean interior and in the subsurface, where the virus-to-prokaryote abundance ratios and the representation of virus-related DNA sequences in metagenomes is typically higher ${ }^{74-79}$. Recent studies provide evidence of a high virus-induced mortality on archaea (mainly on MG-I Thaumarchaeota) in benthic deep-sea ecosystems, resulting in the release of $\sim 0.3$ to 0.5 gigatons of carbon per year globally ${ }^{3}$. MG-I Thaumarchaeota use $\mathrm{CO}_{2}$ to produce biomass, while viruses kill them, releasing their labile cellular content, thus enhancing organic matter remineralization and respiration processes of uninfected heterotrophic microbial components ${ }^{3}$. In turn, the stimulation of heterotrophic processes can enhance nitrogen regeneration processes, supplying 30 to $60 \%$ of the ammonia required to sustain archaeal chemoautotrophic C production in deep-sea sediments ${ }^{3}$. Understanding the factors able to influence this complex network of microbial $\mathrm{CO}_{2}$-consuming and $\mathrm{CO}_{2}$-producing processes will provide insights into the ability of the oceans to act as source or sink for this important greenhouse gas.

Since viral replication is linked with host metabolic state, impacts of global changes on the physiology and metabolism of archaea will likely influence also virus-archaea dynamics ${ }^{80}$. At the same 
time, the success of different archaeal taxa in the future, based on their ability to adapt to the predicted scenarios of global change, will likely influence the relative importance of their viruses. For instance, the changes in the activity, diversity, and distribution of marine bacteria and archaea due to the spreading of oxygen-depleted pelagic and benthic zones ${ }^{69,70}$ will likely determine also shifts in the assemblages of viruses, whose role can be particularly relevant in low-oxygen conditions ${ }^{71,81}$. Similarly, the opposite effects of global changes on primary production and carbon export at high versus middle/tropical latitudes will likely influence in a different way the activity, diversity, and distribution of archaeal viruses on the basis of the different sensitivity to temperature and food availability of their respective archaeal hosts.

Evidence at different latitudes suggests that viral responses to increasing temperature (e.g. viral production rates) display increasing or decreasing trends in polar and in temperate systems, respectively ${ }^{80}$. Further research is needed to understand the role of viruses of archaea in explaining such trends, especially at high latitudes, which host some of the most rapidly warming oceanic regions, as well as large numbers of archaea ${ }^{3,45,60,61}$.

Recent studies carried out in marine ecosystems have pointed out the importance of lysogenic viral infections, in which a provirus coexists in its host until replication is induced, leading or not to cell lysis mainly depending on environmental factors ${ }^{82}$. Taking into account lysogenic viral infections can be critical to predicting changes in bacterial dynamics under scenarios of global change, while such information is currently lacking for archaea ${ }^{83}$. Indeed, despite putative proviruses having been identified in Thaumarchaeota $^{42}$, the relative importance of lytic versus lysogenic virus-archaea dynamics and their response to the environmental changes brought on by global change are still largely unknown.

Considering that viruses can confer novel functions to their host through lateral gene transfer and/or expression of virus-encoded auxiliary metabolic genes ${ }^{84,85}$, we should take into consideration the possibility that such virus-host interactions could influence hosts' responses to global change. Recently, viral auxiliary metabolic genes have been proposed to modulate ammonia oxidation in
Thaumarchaeota ${ }^{4}$, suggesting that future studies on virus-archaea interactions will contribute to clarifying ecological and biogeochemical processes of global relevance.

Overall, global change will alter a wide variety of marine microbialmediated processes, including virus-archaea interactions, which remain as-yet largely unknown despite their significant ecological and biogeochemical implications. Deepening the knowledge on marine virus-archaea dynamics can thus significantly contribute to understanding the ocean's feedbacks on global climate change. The biology, ecology, and evolution of archaea and archaeal viruses is one of the most intriguing and timely topics in microbial ecology, and research perspectives on the marine realm can be extended to freshwater and terrestrial ecosystems, in which archaea are also widespread and diversified ${ }^{86-90}$.

\section{Competing interests}

The authors declare that they have no competing interests.

\section{Grant information}

This work was conducted within the frame of the Flagship Project RITMARE (Italian Research for the Sea) coordinated by the Italian National Research Council and funded by the Italian Ministry of Education, Universities, and Research within the National Research Program 2011-2013, the Project EXPLODIVE (FIRB2008, contract no. I31J10000060001, PICC), the EU Project MIDAS (Managing Impacts of Deep-seA reSource exploitation, grant agreement no. 603418), and the project MERCES (Marine Ecosystem Restoration in Changing European Seas; European Union's Horizon 2020 research and innovation program, grant agreement no. 689518).

The funders had no role in study design, data collection and analysis, decision to publish, or preparation of the manuscript.

\section{Acknowledgements}

The authors would like to thank ENI (Ente Nazionale Idrocarburi) for the ENI Award Protection of the Environment Prize "Marine viruses play a key role in global climate change and in the functioning of the global oceans".
1. Offre P, Spang A, Schleper C: Archaea in biogeochemical cycles. Annu Rev Microbiol. 2013; 67: 437-57. PubMed Abstract | Publisher Full Text

2. Fuhrman JA, Caron DA: Heterotrophic planktonic microbes: virus, bacteria, archaea, and protozoa. In: Manual of Environmental Microbiology. Fourth Edition. American Society of Microbiology; 2016; 4-2. Publisher Full Text

3. Danovaro R, Dell'Anno A, Corinaldesi C, et al.: Virus-mediated archaeal hecatomb in the deep seafloor. Sci Adv. 2016; 2(10): e1600492. PubMed Abstract | Publisher Full Text | Free Full Text

4. Roux S, Brum JR, Dutilh BE, et al.: Ecogenomics and potential biogeochemical impacts of globally abundant ocean viruses. Nature. 2016; 537(7622): 689-93. PubMed Abstract | Publisher Full Text
5. Philosof A, Yutin N, Flores-Uribe J, et al:: Novel Abundant Oceanic Viruses of Uncultured Marine Group II Euryarchaeota. Curr Biol. 2017; 27(9): 1362-8. PubMed Abstract | Publisher Full Text | Free Full Text

6. Nishimura $\mathrm{Y}$, Watai $\mathrm{H}$, Honda $\mathrm{T}$, et al:: Environmental Viral Genomes Shed New Light on Virus-Host Interactions in the Ocean. mSphere. 2017; 2(2). pii: e00359-16. PubMed Abstract | Publisher Full Text | Free Full Text

7. Forterre P: Microbes from Hell. University of Chicago Press; 2016. Reference Source

8. Albers SV: Extremophiles: Life at the deep end. Nature. 2016; 538: 457. Publisher Full Text

9. Prangishvili D, Basta T, Garrett RA, et al.: Viruses of the Archaea. In: eLS. John Wiley \& Sons, Ltd: Chichester. 2016. Publisher Full Text 
10. F Könneke M, Bernhard AE, de la Torre JR, et al.: Isolation of an autotrophic ammonia-oxidizing marine archaeon. Nature. 2005; 437(7058): 543-6. PubMed Abstract | Publisher Full Text | F1000 Recommendation

11. Qin W, Amin SA, Martens-Habbena W, et al:: Marine ammonia-oxidizing archaeal isolates display obligate mixotrophy and wide ecotypic variation. Proc Natl Acad Sci U S A. 2014; 111(34): 12504-9. PubMed Abstract | Publisher Full Text | Free Full Text

12. Park SJ, Ghai R, Martín-Cuadrado AB, et al:: Genomes of two new ammoniaoxidizing archaea enriched from deep marine sediments. PLoS One. 2014; 9(5): e96449.

PublMed Abstract | Publisher Full Text | Free Full Text

13. Santoro AE, Dupont CL, Richter RA, et al.: Genomic and proteomic characterization of "Candidatus Nitrosopelagicus brevis": an ammoniaoxidizing archaeon from the open ocean. Proc Natl Acad Sci U S A. 2015; 112(4): 1173-8.

PubMed Abstract | Publisher Full Text | Free Full Text

14. Bayer B, Vojvoda J, Offre P, et al.: Physiological and genomic characterization of two novel marine thaumarchaeal strains indicates niche differentiation. ISME J. 2016; 10(5): 1051-63.

PubMed Abstract | Publisher Full Text | Free Full Text

15. Li M, Baker BJ, Anantharaman K, et al:: Genomic and transcriptomic evidence for scavenging of diverse organic compounds by widespread deep-sea archaea. Nat Commun. 2015; 6: 8933 PubMed Abstract | Publisher Full Text | Free Full Text

16. F Zaremba-Niedzwiedzka K, Caceres EF, Saw JH, et al.: Asgard archaea Iluminate the origin of eukaryotic cellular complexity. Nature. 2017; 541(7637): 353-8.

PubMed Abstract | Publisher Full Text | F1000 Recommendation

17. Simmonds $\mathrm{P}$, Adams MJ, Benkő M, et al.: Consensus statement: Virus taxonomy in the age of metagenomics. Nat Rev Microbiol. 2017; 15(3): 161-8. PubMed Abstract | Publisher Full Tex

18. F Huber $\mathrm{H}$, Hohn MJ, Rachel R, et al.: A new phylum of Archaea represented y a nanosized hyperthermophilic symbiont. Nature. 2002; 417(6884): 63-7. PubMed Abstract | Publisher Full Text | F1000 Recommendation

19. Brochier-Armanet C, Boussau B, Gribaldo S, et al.: Mesophilic Crenarchaeota: proposal for a third archaeal phylum, the Thaumarchaeota. Nat Rev Microbiol. 2008; 6(3): 245-52.

PubMed Abstract | Publisher Full Tex

20. Nunoura T, Takaki Y, Kakuta J, et al:: Insights into the evolution of Archaea and eukaryotic protein modifier systems revealed by the genome of a nove archaeal group. Nucleic Acids Res. 2011; 39(8): 3204-23. PubMed Abstract | Publisher Full Text | Free Full Text

21. F Evans PN, Parks DH, Chadwick GL, et al:: Methane metabolism in the archaeal phylum Bathyarchaeota revealed by genome-centric metagenomics. Science. 2015; 350(6259): 434-8.

PubMed Abstract | Publisher Full Text | F1000 Recommendation

22. F Vanwonterghem I, Evans PN, Parks DH, et al:: Methylotrophic methanogenesis discovered in the archaeal phylum Verstraetearchaeota. Nat Microbiol. 2016; 1: 16170.

PubMed Abstract | Publisher Full Text | F1000 Recommendation

23. F Raymann $\mathrm{K}$, Brochier-Armanet $\mathrm{C}$, Gribaldo $\mathrm{S}$ : The two-domain tree of life is linked to a new root for the Archaea. Proc Natl Acad Sci U S A. 2015; 112(21): $6670-5$.

PubMed Abstract | Publisher Full Text | Free Full Text | F1000 Recommendation

24. F Hug LA, Baker BJ, Anantharaman K, et al.: A new view of the tree of life. Nat Microbiol. 2016; 1: 16048

PubMed Abstract | Publisher Full Text | F1000 Recommendation

25. Lloyd KG, Schreiber L, Petersen DG, et al:: Predominant archaea in marine sediments degrade detrital proteins. Nature. 2013; 496(7444): 215-8. PubMed Abstract | Publisher Full Text

26. F He Y, Li M, Perumal V, et al.: Genomic and enzymatic evidence for acetogenesis among multiple lineages of the archaeal phylum Bathyarchaeota acetogenesis among multiple lineages of the archaeal phylum Bath
widespread in marine sediments. Nat Microbiol. 2016; 1(6): 16035. widespread in marine sediments. Nat Microbiol. 2016; 1(6): 16035.
PubMed Abstract | Publisher Full Text | F1000 Recommendation

27. F Castelle CJ, Wrighton KC, Thomas BC, et al.: Genomic expansion of domain archaea highlights roles for organisms from new phyla in anaerobic carbon cycling. Curr Biol. 2015; 25(6): 690-701.

PubMed Abstract | Publisher Full Text | F1000 Recommendation

28. F Eloe-Fadrosh EA, Ivanova NN, Woyke T, et al:: Metagenomics uncovers gaps in amplicon-based detection of microbial diversity. Nat Microbiol. 2016; 1 : 15032.

PubMed Abstract | Publisher Full Text | F1000 Recommendation

29. Cobián Güemes AG, Youle M, Cantú VA, et al:: Viruses as Winners in the Game of Life. Annu Rev Virol. 2016; 3(1): 197-214.

PubMed Abstract | Publisher Full Text

30. Armbrust EV, Palumbi SR: Marine biology. Uncovering hidden worlds of ocean biodiversity. Science. 2015; 348(6237): 865-7.

PubMed Abstract | Publisher Full Text

31. Danovaro R, Corinaldesi C, Rastelli E, et al: Towards a better quantitative assessment of the relevance of deep-sea viruses, Bacteria and Archaea in th functioning of the ocean seafloor. Aquat Microb Ecol. 2015; 75: 81-90. Publisher Full Text

32. Corinaldesi C: New perspectives in benthic deep-sea microbial ecology. Front Mar Sci. 2015; 2: 17 Publisher Full Text

33. F Qin W, Meinhardt KA, Moffett JW, et al.: Influence of oxygen availability on the activities of ammonia-oxidizing archaea. Environ Microbiol Rep. 2017; 9(3) 250-6.

PubMed Abstract | Publisher Full Text | F1000 Recommendation

34. Needham DM, Fuhrman JA: Pronounced daily succession of phytoplankton, archaea and bacteria following a spring bloom. Nat Microbiol. 2016; 1: 16005. PubMed Abstract | Publisher Full Text

35. F Martin-Cuadrado AB, Garcia-Heredia I, Moltó AG, et al:: A new class of marine Euryarchaeota group II from the Mediterranean deep chlorophyll maximum. ISME J. 2015; 9(7): 1619-34.

PubMed Abstract | Publisher Full Text | Free Full Text | F1000 Recommendation

36. F Orsi WD, Smith JM, Liu S, et al:: Diverse, uncultivated bacteria and archaea underlying the cycling of dissolved protein in the ocean. ISME J. 2016; 10(9): 2158-73.

PubMed Abstract | Publisher Full Text | Free Full Text | F1000 Recommendation

37. Haro-Moreno JM, Rodriguez-Valera F, López-García $P$, et al:: New insights into marine group III Euryarchaeota, from dark to light. ISME J. 2017; 11(5): 1102-17. PubMed Abstract | Publisher Full Text | Free Full Text

38. Lloyd KG, May MK, Kevorkian RT, et al:: Meta-analysis of quantification methods shows that archaea and bacteria have similar abundances in the subseafloor. Appl Environ Microbiol. 2013; 79(24): 7790-9.

PubMed Abstract | Publisher Full Text | Free Full Tex

39. Teske A: Archaea in deep marine subsurface sediments. Microbial Life of the Deep Biosphere. Kallmeyer J, Wagner D, Eds. 2014; 143-160. Publisher Full Text

40. Rotaru AE, Thamdrup B: BIOGEOCHEMISTRY. A new diet for methane oxidizers Science. 2016: 351(6274): 658.

PubMed Abstract | Publisher Full Text

41. F Wegener G, Krukenberg V, Riedel D, et al.: Intercellular wiring enables electron transfer between methanotrophic archaea and bacteria. Nature. 2015; 526(7574): 587-90.

PubMed Abstract | Publisher Full Text | F1000 Recommendation

42. Krupovic M, Spang A, Gribaldo S, et al.: A thaumarchaeal provirus testifies for an ancient association of tailed viruses with archaea. Biochem Soc Trans. 2011; 39(1): 82-8.

PubMed Abstract | Publisher Full Text

43. Chow CE, Winget DM, White RA 3rd, et al:: Combining genomic sequencing methods to explore viral diversity and reveal potential virus-host interactions. Front Microbiol. 2015; 6: 265.

PubMed Abstract | Publisher Full Text | Free Full Text

44. Labonté JM, Swan BK, Poulos B, et al.: Single-cell genomics-based analysis of virus-host interactions in marine surface bacterioplankton. ISME J.2015; 9(11): 2386-99. PubMed Abstract | Publisher Full Text | Free Full Text

45. Danovaro R, Molari M, Corinaldesi C, et al.: Macroecological drivers of archaea and bacteria in benthic deep-sea ecosystems. Sci Adv. 2016; 2(4): e1500961. PubMed Abstract | Publisher Full Text | Free Full Text

46. F Paul BG, Bagby SC, Czornyj E, et al:: Targeted diversity generation by intraterrestrial archaea and archaeal viruses. Nat Commun. 2015; 6: 6585. PubMed Abstract | Publisher Full Text | Free Full Text | F1000 Recommendation

47. $\mathrm{F}$ Nigro OD, Jungbluth SP, Lin HT, et al:: Viruses in the Oceanic Basement. MBio. 2017; 8(2): pii: e02129-16.

PubMed Abstract | Publisher Full Text | Free Full Text | F1000 Recommendation

48. Lima-Mendez G, Faust K, Henry N, et al:: Ocean plankton. Determinants of community structure in the global plankton interactome. Science. 2015; 348(6237): 1262073

PubMed Abstract | Publisher Full Text

49. WMO Greenhouse Gas Bulletin: The State of Greenhouse Gases in the Atmosphere Based on Global Observations through 2015. World Meteorological Organization, 2016

Reference Source

50. Tian H, Lu C, Ciais $\mathrm{P}$, et al.: The terrestrial biosphere as a net source of greenhouse gases to the atmosphere. Nature. 2016; 531(7593): 225-8. PubMed Abstract | Publisher Full Text

51. Pörtner HO, Karl DM, Boyd PW, et al.: Ocean systems. In: Climate Change 2014: Impacts, Adaptation, and Vulnerability. Part A: Global and Sectoral Aspects. Contribution of Working Group II to the Fifth Assessment Report of the Intergovernmental Panel on Climate Change. Field CB, VR Barros, DJ Dokken, et al.: (eds.)]. Cambridge University Press, Cambridge, United Kingdom and New York, NY, USA. 2014; 411-484.

Reference Source

52. F Halpern BS, Frazier M, Potapenko J, et al:: Spatial and temporal changes in cumulative human impacts on the world's ocean. Nat Commun. 2015: 6.7615. PubMed Abstract | Publisher Full Text | Free Full Text | F1000 Recommendation 
53. F Nagelkerken I, Connell SD: Global alteration of ocean ecosystem functioning due to increasing human $\mathrm{CO}_{2}$ emissions. Proc Natl Acad Sci U S A. 2015; 112(43): 13272-7.

PubMed Abstract | Publisher Full Text | Free Full Text | F1000 Recommendation

54. Pointing SB, Fierer N, Smith GJ, et al:: Quantifying human impact on Earth's microbiome. Nat Microbiol. 2016; 1(9): 16145. PubMed Abstract | Publisher Full Text

55. F Henson SA, Beaulieu C, llyina $\mathrm{T}$, et al.: Rapid emergence of climate change in environmental drivers of marine ecosystems. Nat Commun. 2017; 8: 14682. PubMed Abstract | Publisher Full Text | Free Full Text | F1000 Recommendation

56. Könneke M, Schubert DM, Brown PC, et al:: Ammonia-oxidizing archaea use the most energy-efficient aerobic pathway for $\mathrm{CO}_{2}$ fixation. Proc Natl Acad Sci U S A. 2014; 111(22): 8239-44.

PubMed Abstract | Publisher Full Text | Free Full Text

57. Molari M, Manini E, Dell'Anno A: Dark inorganic carbon fixation sustains the functioning of benthic deep-sea ecosystems. Global Biogeochem Cy. 2013; 27(1): 212-221.

Publisher Full Text

58. Scheller S, Yu H, Chadwick GL, et al: Artificial electron acceptors decouple archaeal methane oxidation from sulfate reduction. Science. 2016; 351(6274): 703-7. PubMed Abstract | Publisher Full Text

59. Cavicchioli R: Microbial ecology of Antarctic aquatic systems. Nat Rev Microbiol. 2015; 13(11): 691-706.

PubMed Abstract | Publisher Full Text

60. Alonso-Sáez L, Waller AS, Mende DR, et al:: Role for urea in nitrification by polar marine Archaea. Proc Natl Acad Sci U S A. 2012; 109(44): 17989-94. PubMed Abstract | Publisher Full Text | Free Full Text

61. Tolar BB, Ross MJ, Wallsgrove NJ, et al: Contribution of ammonia oxidation to chemoautotrophy in Antarctic coastal waters. ISME J. 2016: 10(11): 2605-19. PubMed Abstract | Publisher Full Text | Free Full Text

62. F Arrigo KR, van Dijken GL: Continued increases in Arctic Ocean primary production. Progr Oceanogr. 2015; 136: 60-70. Publisher Full Text | F1000 Recommendation

63. F Holding JM, Duarte CM, Sanz-Martín M, et al:: Temperature dependence of $\mathrm{CO}_{2}$-enhanced primary production in the European Arctic Ocean. Nat Clim Change. 2015; 5(12): 1079-1082. Publisher Full Text | F1000 Recommendation

64. F Moreau S, Mostajir B, Bélanger S, et al.: Climate change enhances primary production in the western Antarctic Peninsula. Glob Chang Biol. 2015; 21(6): 2191-205.

PubMed Abstract | Publisher Full Text | F1000 Recommendation

65. Sweetman AK, Thurber AR, Smith CR, et al:: Major impacts of climate change on deep-sea benthic ecosystems. Elem Sci Anth. 2017; 5: 4 . Publisher Full Text

66. Horak RE, Qin W, Schauer AJ, et al: Ammonia oxidation kinetics and temperature sensitivity of a natural marine community dominated by Archaea. ISME J. 2013; 7(10): 2023-33.

PubMed Abstract | Publisher Full Text | Free Full Text

67. F Boetius A, Anesio AM, Deming JW, et al.: Microbial ecology of the cryosphere: sea ice and glacial habitats. Nat Rev Microbiol. 2015; 13(11): $677-90$.

PubMed Abstract | Publisher Full Text | F1000 Recommendation

68. Deming JW, Collins RE: Sea ice as a habitat for Bacteria, Archaea and viruses. Sea Ice. 2017; 326-351.

Publisher Full Text

69. Ulloa O, Canfield DE, DeLong EF, et al:: Microbial oceanography of anoxic oxygen minimum zones. Proc Natl Acad Sci U S A. 2012; 109(40): 15996-6003. PubMed Abstract | Publisher Full Text | Free Full Text

70. Wright JJ, Konwar KM, Hallam SJ: Microbial ecology of expanding oxygen minimum zones. Nat Rev Microbiol. 2012; 10(6): 381-94. PubMed Abstract | Publisher Full Text

71. Rastelli E, Corinaldesi C, Petani B, et al:: Enhanced viral activity and dark $\mathrm{CO}_{2}$ fixation rates under oxygen depletion: the case study of the marine Lake Rogoznica. Environ Microbiol. 2016; 18(12): 4511-22. PubMed Abstract | Publisher Full Text

72. Suttle CA: Marine viruses--major players in the global ecosystem. Nat Rev Microbiol. 2007; 5(10): 801-12. PubMed Abstract | Publisher Full Text
73. Mojica KD, Huisman J, Wilhelm SW, et al:: Latitudinal variation in virus-induced mortality of phytoplankton across the North Atlantic Ocean. ISME J. 2016; 10(2): 500-13.

PubMed Abstract | Publisher Full Text | Free Full Text

74. Luna GM, Corinaldesi C, Rastelli E, et al:: Patterns and drivers of bacterial $\alpha$ - and $\beta$-diversity across vertical profiles from surface to subsurface sediments. Environ Microbiol Rep. 2013; 5(5): 731-9.

PubMed Abstract | Publisher Full Text

75. $\mathrm{F}$ Engelhardt $\mathrm{T}$, Kallmeyer $\mathrm{J}$, Cypionka $\mathrm{H}$, et al:: High virus-to-cell ratios indicate ongoing production of viruses in deep subsurface sediments. ISME J. 2014; 8(7): 1503-9.

PubMed Abstract | Publisher Full Text | Free Full Text | F1000 Recommendation

76. F Nunoura T, Takaki Y, Hirai M, et al:: Hadal biosphere: insight into the microbial ecosystem in the deepest ocean on Earth. Proc Natl Acad Sci U S A. 2015; 112(11): E1230-6.

PubMed Abstract | Publisher Full Text | Free Full Text | F1000 Recommendation

77. Konstantinidis $\mathrm{KT}$, Braff $\mathrm{J}$, Karl DM, et al:: Comparative metagenomic analysis of a microbial community residing at a depth of 4,000 meters at station ALOHA in the North Pacific subtropical gyre. Appl Environ Microbiol. 2009; 75(16): in the No $345-55$.

PubMed Abstract | Publisher Full Text | Free Full Text

78. Smedile F, Messina E, La Cono V, et al:: Metagenomic analysis of hadopelagic microbial assemblages thriving at the deepest part of Mediterranean Sea, Matapan-Vavilov Deep. Environ Microbiol. 2013; 15(1): 167-82.

PubMed Abstract | Publisher Full Text

79. Corinaldesi C, Dell'Anno A, Danovaro R: Viral infections stimulate the metabolism and shape prokaryotic assemblages in submarine mud volcanoes. ISME J. 2012; 6(6): 1250-9.

PubMed Abstract | Publisher Full Text | Free Full Text

80. Danovaro R, Corinaldesi C, Dell'Anno A, et al:: Marine viruses and global climate change. FEMS Microbiol Rev. 2011; 35(6): 993-1034.

PubMed Abstract | Publisher Full Text

81. Corinaldesi C, Tangherlini M, Luna GM, et al:: Extracellular DNA can preserve the genetic signatures of present and past viral infection events in deep hypersaline anoxic basins. Proc Biol Sci. 2014; 281(1780): 20133299. PubMed Abstract | Publisher Full Text | Free Full Text

82. F Knowles B, Silveira $\mathrm{CB}$, Bailey BA, et al.: Lytic to temperate switching of viral communities. Nature. 2016; 531(7595): 466-70.

PubMed Abstract | Publisher Full Text | F1000 Recommendation

83. Brum JR, Hurwitz BL, Schofield O, et al.: Seasonal time bombs: dominant temperate viruses affect Southern Ocean microbial dynamics. ISME J. 2016; 10(2): 437-49.

PubMed Abstract | Publisher Full Text | Free Full Text

84. F Hurwitz BL, U'Ren JM: Viral metabolic reprogramming in marine ecosystems. Curr Opin Microbiol. 2016; 31: 161-8.

PubMed Abstract | Publisher Full Text | F1000 Recommendation

85. F Rosenwasser S, Ziv C, van Creveld SG, et al.: Virocell Metabolism: Metabolic Innovations During Host-Virus Interactions in the Ocean. Trends Microbiol. 2016; 24(10): 821-32.

PubMed Abstract | Publisher Full Text | F1000 Recommendation

86. Auguet JC, Barberan A, Casamayor EO: Global ecological patterns in uncultured Archaea. ISME J. 2010; 4(2): 182-90.

PubMed Abstract | Publisher Full Text

87. Berdjeb L, Pollet T, Chardon C, et al.: Spatio-temporal changes in the structure of archaeal communities in two deep freshwater lakes. FEMS Microbiol Ecol. 2013; 86(2): 215-30.

PubMed Abstract | Publisher Full Text

88. Ettwig KF, Zhu B, Speth D, et al:: Archaea catalyze iron-dependent anaerobic oxidation of methane. Proc Natl Acad Sci U S A. 2016; 113(45): 12792-96, pii: 201609534.

PubMed Abstract | Publisher Full Text | Free Full Text

89. Narrowe AB, Angle JC, Daly RA, et al:: High-resolution sequencing reveals unexplored archaeal diversity in freshwater wetland soils. Environ Microbiol. 2017; 19(6): 2192-209.

PubMed Abstract | Publisher Full Text

90. Lin Y, Liu D, Yuan J, et al.: Methanogenic Community Was Stable in Two Contrasting Freshwater Marshes Exposed to Elevated Atmospheric $\mathrm{CO}_{2}$. Front Microbiol. 2017; 8: 932.

PubMed Abstract | Publisher Full Text | Free Full Text 


\section{Open Peer Review}

\section{Current Peer Review Status:}

\section{Editorial Note on the Review Process}

Faculty Reviews are review articles written by the prestigious Members of Faculty Opinions. The articles are commissioned and peer reviewed before publication to ensure that the final, published version is comprehensive and accessible. The reviewers who approved the final version are listed with their names and affiliations.

\section{The reviewers who approved this article are:}

\section{Version 1}

\section{Jed A. Fuhrman} Department of Biological Sciences, University of Southern California, Los Angeles, CA, USA Competing Interests: No competing interests were disclosed.

\section{Stéphan Jacquet}

Institut National de la Recherche Agronomique, UMR CARRTEL, Thonon-les-Bains, France

Competing Interests: No competing interests were disclosed.

The benefits of publishing with F1000Research:

- Your article is published within days, with no editorial bias

- You can publish traditional articles, null/negative results, case reports, data notes and more

- The peer review process is transparent and collaborative

- Your article is indexed in PubMed after passing peer review

- Dedicated customer support at every stage

For pre-submission enquiries, contact research@f1000.com 